\title{
Intervensi Dengan Pendekatan Cognitive Behavior Therapy untuk Mengurangi Diabetes-Related Distress pada Lanjut Usia dengan Penyakit Diabetes Mellitus Tipe 1 dan Tipe 2
}

\section{Cognitive Behavior Therapy Appruach to Reduce Diabetic Related Distress Elderly Diabetes Mellitus Type 1 and 2 Patients}

\author{
Chandradewi Kusristanti ${ }^{1}$, Dharmayati Utoyo Lubis ${ }^{2}$ \\ ${ }^{I}$ Fakultas Psikologi Universitas YARSI \\ ${ }^{2}$ Fakultas Psikologi Universitas Indonesia \\ E-mail: chandradewi.kusristanti@yarsi.ac.id
}

KEYWORDS Cognitive behavior therapy, diabetes-related distress, older adults

ABSTRACT Diabetes Mellitus (DM) is one of the most frequent disorders distributed globally. Many drugs or regimens being used, complication risks, and various factors may induce diabetes-related distress in DM patients. Many studies have found that the presence of diabetes-related distress may provide negative impacts to patients, physically and psychologically. In older patients, the negative impacts may be worsened by the characteristics of older individuals. Having acknowledged those negative impacts to older DM patients, this study was aimed to learn the influence of cognitive behavior therapy approach to reduce diabetes-related distress in older DM patients. Two participants were selected in this study, both are older adults with high level of diabetes-related distress. All participants experienced decreased level of diabetes-related distress from their participation in this intervention, as shown during interview, observation, and assessment using PAID (Problem Areas In Diabetes) questionnaire. All participants were able to practice the respective techniques. All participants also understand that the therapeutic success is determined by their independence and their willingness to change by practicing it in daily life.

\section{PENDAHULUAN}

Diabetes Mellitus (DM) merupakan salah satu penyakit yang paling sering muncul di dunia (Sarafino \& Smith, 2011). Secara singkat, DM merupakan penyakit yang disebabkan oleh kelebihan kadar gula dalam darah sebagai akibat dari ketidakmampuan pankreas memproduksi hormon insulin. Penyakit DM ini terdiri dari dua jenis, yaitu DM tipe 1 (insulin-dependent DM) dan DM tipe 2 (non-insulin DM). Dari berbagai sumber disebutkan bahwa International Diabetes Federation memperkirakan bahwa akan terjadi peningkatan jumlah penderita DM di Indonesia, dari yang sebelumnya berjumlah 7 juta orang di tahun 2009 akan meningkat menjadi 12 juta orang pada tahun 2030 mendatang. Pada tahun 2010, WHO (World Health Organization) telah merilis data bahwa Indonesia merupakan negara dengan jumlah penderita DM terbesar keempat di dunia. Meskipun implikasi DM dapat menyebabkan kematian pada penderitanya, sebenarnya terdapat 
sejumlah regimen yang dapat dilakukan penderita DM terkait manajemen penyakitnya. Regimen yang harus dilakukan tersebut akan disesuaikan dengan tipe DM yang dimiliki individu yang bersifat self-care. Regimen tersebut di antaranya adalah mengontrol berat badan, mengontrol asupan makanan, melakukan tes darah secara berkala, meminum obat, berolahraga, dan lain sebagainya. Halter (1999, dalam Franks, dkk, 2010) mengemukakan bahwa manajemen DM membutuhkan kepatuhan (adherence) yang sangat besar.

Sejumlah penelitian tentang DM menyimpulkan bahwa diabetes-related distress, khususnya yang terkait dengan regimen DM sehari-hari, sangat sering ditemukan pada penderita DM (Franks, $\mathrm{dkk}, 2010)$. Penelitian yang dilakukan oleh Lustman, dkk (2005) menemukan bahwa adanya diabetes-related distress dapat memperburuk kontrol glikemik pada penderita DM. Secara umum, efek dari stres terhadap regulasi glukosa merupakan topik yang beberapa kali dibahas dalam penelitian mengenai DM. Stres akut menyebabkan adanya reaksi fisiologis dan mempengaruhi kondisi psikologis pada penderita DM. Reaksi fisiologis tersebut di antaranya seperti peningkatan detak jantung, penyempitan pembuluh darah pada sistem vaskular perifer, dan peningkatan aktivitas otot, peningkatan produksi hormon pituiter, katekolamin, kortikosteroid, dan supresi pada pelepasan insulin.

Sementara itu, kondisi psikologis pada penderita DM yang mengalami diabetes-related distress dalam tingkat yang cukup tinggi memiliki motivasi yang rendah untuk menjalankan regimen yang bersifat self-care, seperti perilaku makan sehat dan olahraga (Munshi \& Lipsitz, 2007). Efek psikologis lainnya dari stres yang dialami penderita DM adalah besarnya kemungkinan mereka untuk mengalami depresi. Sejumlah penelitian menemukan bahwa depresi dan diabetes-related distress memberikan dampak yang buruk yaitu dapat meningkatkan risiko komplikasi dan kematian (Faber-Wildeboer, dkk., 2012). Dari sejumlah penelitian yang dilakukan mengenai depresi dan diabetes-related distress, ditemukan bahwa yang termasuk ke dalam faktor risiko adalah gender perempuan, usia di atas 64 tahun, pendidikan rendah, adanya komplikasi, peristiwa hidup yang besar, kontrol glikemik yang buruk, serta pengobatan insulin (Faber-Wildeboer, dkk., 2012).

$$
\text { Sejumlah penelitian tentang }
$$
berbagai intervensi psikologis menemukan bahwa cognitive behavior therapy (CBT) telah banyak digunakan untuk mengurangi kadar distres psikologis pada penderita DM tipe 1 dan tipe 2 (Davazdahemamy, dkk., 2012). Menurut Lustman, Griffith, Freedland, Kissel dan Clouse (1998) menemukan bahwa pendekatan berbasis CBT terbukti efektif untuk mengurangi stres pada penderita DM tipe 2. Selanjutnya, penelitian yang dilakukan oleh Snoek, dkk (1999) menyimpulkan bahwa intervensi berbentuk psikoedukasi kelompok berbasis CBT terhadap penderita DM tipe 1 dengan kontrol glikemik yang rendah cukup efektif dalam membantu mereka melakukan coping terkait dengan regimen DM. Meskipun terdapat sejumlah penelitian yang telah menemukan bukti efektivitas penerapan intervensi berbasis CBT terhadap stres yang dialami oleh penderita DM, namun belum ada penelitian yang membahas secara spesifik tentang penerapan CBT terhadap manajemen stres pada penderita CBT berusia lanjut. Sama halnya dengan masalah emosional yang paling banyak diteliti adalah depresi (Pouwer, 2009), sedangkan masalah emosional lainnya seperti diabetes-related distress masih sangat jarang diteliti. Dengan demikian, peneliti tertarik untuk 

DENGAN PENYAKIT DIABETES MELLITUS TIPE 1 DAN TIPE 2

menerapkan intervensi berbasis CBT untuk mengatasi diabetes-related distress pada individu dengan DM tipe 1 dan tipe 2 yang berusia lanjut, mengingat paparan sebelumnya bahwa usia lanjut merupakan salah satu faktor risiko. Apabila intervensi tersebut terbukti efektif, maka diharapkan intervensi tersebut dapat meningkatkan pilihan intervensi bagi penderita DM, khususnya yang berusia lanjut.

\section{METODOLOGI}

Penelitian ini memiliki karakteristik partisipan berupa laki-laki atau perempuan berusia minimal 60 tahun, telah mendapatkan diagnosis dokter bahwa dirinya menderita DM, berada dalam golongan distres tinggi menurut skor kuesioner Problem Areas In Diabetes (PAID), dan bersedia mengikuti seluruh rangkaian penelitian. Dalam penelitian ini, teknik sampling yang digunakan adalah teknik non-probability sampling berupa purposive sampling.

Penelitian ini menggunakan desain pre-test/post-test, yaitu asesmen pertama dilakukan sebelum intervensi dimulai, dan asesmen berikutnya dilakukan setelah intervensi selesai diberikan. Intervensi pada penelitian ini diberikan kepada dua orang partisipan. Perilaku yang diobservasi adalah kemunculan negative automatic thought (NAT) dan tingkat distres yang dialami oleh partisipan. NAT yang dimiliki oleh partisipan diketahui melalui hasil wawancara pada asesmen awal, sementara tingkat distres diukur melalui kuesioner PAID.

Intervensi yang akan digunakan dalam penelitian ini adalah pendekatan cognitive behavior therapy (CBT). Dalam proses intervensi ini, peneliti sebagai terapis akan memfasilitasi partisipan sebagai klien untuk mengenali masalah serta NATs yang dimilikinya. Selama intervensi, peneliti mencatat semua proses yang berlangsung.

Penelitian ini menggunakan alat ukur Problem Areas In Diabetes (PAID) untuk mengukur responsivitas emosional spesifik pada penderita DM. Alat ukur ini terdiri dari 20 item dan diukur menggunakan skala Likert. Semakin besar skor mengindikasikan semakin besarnya distres emosional yang dialami. Skor cut-off sebesar 50 menunjukkan bahwa individu mengalami distres emosional yang tinggi, sehingga membutuhkan intervensi secepat mungkin. Pada penelitian sebelumnya, diketahui alat ukur PAID memiliki konsistensi internal sebesar 0.90 dan reliabilitas test-retest sebesar 0.83 . Kemudian peneliti melakukan pengujian reliabilitas alat ukur dengan metode internal konsistensi. Uji reliabilitas alat ukur diberikan kepada lansia di daerah Depok $(\mathrm{N}=31)$. Hasil uji reliabilitas yang dilakukan menunjukkan bahwa alat ukur yang digunakan memiliki reliabilitas yang baik $(\alpha=0,88)$.

\section{Tahap Persiapan Intervensi}

Setelah mendapatkan 31 orang penderita DM yang bersedia mengisi kuesioner PAID, terdapat 13 orang yang masuk ke dalam kategori distres berat berdasarkan skor cut-off PAID, namun yang bersedia untuk menjalani rangkaian intervensi hanya 1 orang. Peneliti kemudian mencari partisipan lagi di lingkungan sekitar kediaman peneliti, dan mendapatkan 1 orang sesuai kriteria yang bersedia untuk menjalani intervensi.

Intervensi dalam penelitian ini dirancang untuk 7 sesi. Waktu pada tiap sesi berkisar antara 60 hingga 90 menit. Waktu tesebut disesuaikan dengan kesediaan partisipan. Berdasarkan kesepakatan bersama, setiap sesi intervensi akan dilaksanakan di kediaman masing-masing partisipan. 
Selain memberikan intervensi, penelitian ini juga memasukkan komponen psikoedukasi serta relaksasi progresif ke dalam rangkaian intervensi. Psikoedukasi diberikan untuk membantu klien lebih memahami tentang penyakit DM yang dideritanya dan menjelaskan hubungan antara DM dengan distres yang dialami serta dampaknya terhadap DM yang diderita. Sementara itu, relaksasi progresif diberikan dengan tujuan agar klien dapat mempraktikkan relaksasi tersebut saat dirinya mengalami stres di kemudian hari.

Secara garis besar, tahap evaluasi penelitian ini dilakukan melalui pendekatan kuantitatif dan kualitatif. Peneliti melihat efektivitas intervensi melalui tiga cara, yaitu kemunculan NATs sebelum dan setelah intervensi, wawancara mengenai manfaat yang dirasakan pasca intervensi, serta skor PAID yang diambil setelah seluruh rangkaian intervensi berhasil dilakukan.

\section{Rancangan Intervensi}

Secara singkat, masing-masing sesi intervensi yang akan dilakukan antara lain, sesi 1 (identifikasi masalah); sesi 2 (psikoedukasi); sesi 3 (relaksasi progresif dan psikoedukasi $\mathrm{ABC}$ ); sesi 4 (pembahasan tugas rumah dan identifikasi NATs); sesi 5 (teknik counter NATs); sesi 6 (pembahasan tugas rumah dan relapse management); dan sesi 7 (terminasi).

\section{Asesmen Awal}

Asesmen awal pada partisipan bertujuan untuk mengetahui kesesuaian partisipan dengan karakteristik partisipan yang ditetapkan untuk penelitian ini. Karakteristik partisipan adalah individu lanjut usia yang mengidap DM dan berada pada golongan distres berat berdasarkan hasil asesmen Problem Areas In Diabetes (PAID).

Setelah proses asesmen dilakukan, didapatkan dua partisipan, yaitu A dan R.
Dari kuesioner PAID yang diisi oleh A, ditemukan bahwa terdapat 10 area yang dirasa mengganggu (mendapatkan skor 2 - 5). Area-area tersebut di antaranya adalah kekhawatiran atas dampak gula darah, merasa bersalah saat melakukan hal yang menyalahi regimen DM, serta kejenuhan dalam mengatasi DM. Sementara itu, partisipan $\mathrm{R}$ memiliki 9 area yang dirasa mengganggu (skor 2 5). Area tersebut di antaranya adalah dukungan sosial dari orang sekitar, kekhawatiran atas komplikasi DM, dan kejenuhan mengatasi DM.

\section{Hasil Observasi dan Wawancara Partisipan}

Partisipan A adalah seorang pria berusia 63 tahun. Ia bertinggi badan sekitar $168 \mathrm{~cm}$ dengan berat badan kurang lebih $65 \mathrm{~kg}$. Sementara itu, partisipan $\mathrm{R}$ adalah seorang wanita berusia 60 tahun dan bertinggi badan sekitar $160 \mathrm{~cm}$ serta memiliki berat badan sekitar $70 \mathrm{~kg}$. Keduanya memiliki warna kulit kuning langsat, dan pada kaki keduanya terdapat sejumlah bercak hitam.

A merupakan penderita DM tipe 2, sedangkan $\mathrm{R}$ merupakan seorang penderita DM tipe 1 yang menderita glaukoma sebagai dampak dari DM. Dengan demikian, ia tidak dapat melihat dengan jelas. Hal tersebut membuat pergerakannya menjadi terbatas sehingga selama proses penelitian $\mathrm{R}$ dibantu oleh peneliti dalam pengisian kuesioner ataupun lembar kerja.

Partisipan A telah menderita DM tipe 2 sejak tahun 1993. Penyakitnya tersebut berakar dari gaya hidupnya yang kurang sehat. Sejak beberapa tahun sebelum dirinya mendapatkan DM, ia memiliki kebiasaan minum setengah liter teh manis setiap pagi dan kerap mengonsumsi kudapan manis di siang hari, serta jarangnya melakukan rutinitas olahraga. Setelah didiagnosis DM, A 
menjadi lebih teratur minum obat setiap hari dan teratur dalam berolahraga, serta ia juga menjadi sangat ketat dalam menjaga pola makannya. Akhir-akhir ini, A merasa sudah bosan dalam menjalani rutinitas regimen. Dilatarbelakangi oleh rasa bosan tersebut, sesekali A melanggar pola makannya dan mengonsumsi makanan dalam jumlah lebih besar dari yang dibolehkan ataupun mengonsumsi makanan yang tidak dibolehkan. Partisipan R telah divonis menderita DM tipe 1 sejak 40 tahun lalu. Setelah dilakukan pemeriksaan, ditemukan bahwa B memiliki kadar gula darah sebesar 300 $\mathrm{mg} / \mathrm{dl}$. Sama halnya dengan partisipan A, $\mathrm{R}$ pun juga menjadi rajin berolahraga dan ia masih aktif mengelola salon miliknya. Ia merasa hal yang paling sulit dari hidup dengan DM adalah keharusannya untuk menaati regimen DM, salah satunya adalah menjaga pola makan. Selama 3 tahun terakhir, $\mathrm{R}$ tidak mampu lagi melihat dengan jelas. Ia hanya mampu melihat dengan sangat samar. Hal itu dilatarbelakangi oleh salah satu komplikasi dari DM, yaitu glaukoma, yang dideritanya.

\section{ISI}

\section{Sesi 1 : Identifikasi Masalah}

Partisipan A

Berikut adalah komponen masalah yang dimiliki oleh A:

Faktor kerentanan: Kebiasaan makan enak dengan porsi yang tidak dibatasi

Precipitant: Istri kurang tegas mengawasi pola makan; melihat orang lain bisa makan enak

Asumsi/Belief: Kenaikan gula darah bukan merupakan suatu masalah

Pemicu: Orang-orang di sekitar A yang bisa makan enak di manapun

Seluruh faktor tersebut kemudian berinteraksi dan menimbulkan masalah, yaitu sebagai berikut:
Aspek pikiran: Berpikir bahwa tidak apa-apa apabila gula darah sedikit naik Emosi: Merasa bosan dan tertekan Tingkah laku: Apabila ada kesempatan, A tidak ragu melanggar pola makan untuk makan enak Fisiologis: Mengalami kenaikan kadar gula dalam darah

\section{Partisipan R}

Berikut adalah komponen masalah yang dimiliki oleh R:

Faktor kerentanan: $\mathrm{R}$ merupakan individu yang mandiri dan gemar berinteraksi di lingkungan sosial Precipitant: Terjatuh di depan umum sehingga harus dibantu oleh banyak orang

Asumsi/ Belief: Merasa tidak berdaya karena harus dibantu oleh orang lain akibat glaukoma yang dimilikinya sebagai dampak DM tipe 1 yang dideritanya

Pemicu: Adanya beberapa kegiatan yang sekarang tidak dapat lagi diikuti olehnya sebagai dampak dari glaukoma yang dimilikinya

Seluruh faktor tersebut kemudian berinteraksi dan menimbulkan masalah, yaitu sebagai berikut:

Aspek pikiran: Berpikir bahwa ia tidak bisa lagi bergaul seperti dulu dan bahwa dirinya membebani orang lain Emosi: Merasa sedih dan tidak berdaya

Tingkah laku: $\mathrm{R}$ memilih untuk berdiam diri di rumah dan menolak saat diajak bergaul dengan tetangga Fisiologis: Mengalami sulit tidur

\section{Sesi 2 : Psikoedukasi}

Sesi ini berfokus pada penyampaian informasi mengenai DM, serta hubungan antara kondisi psikologis dan fisiologis penderita DM. Peneliti juga menyampaikan tentang teknik coping stres yang dapat dilakukan oleh kedua partisipan. 


\section{Sesi 3 : Relaksasi Progresif dan Psikoedukasi ABC}

Pada sesi ini, peneliti mengajarkan mengenai teknik relaksasi progresif. Selanjutnya, peneliti menjelaskan tentang konsep $\mathrm{ABC}$, yaitu interaksi antara situasi (A), pemikiran (B), dan konsekuensi (C) sebagai konsep dasar terapi CBT. Untuk membantu pemahaman partisipan, peneliti melengkapi penjelasan tersebut dengan contoh, Peneliti kemudian mengajak kedua partisipan untuk mengerjakan isian tentang konsep ABC yang dimiliki oleh dirinya masing- masing.

\section{Sesi 4 : Pembahasan Tugas Rumah dan Identifikasi Pikiran Negatif Otomatis (NATs)}

Pada sesi ini, peneliti membahas tugas rumah yang dikerjakan oleh kedua partisipan. Salah satu yang materi pembahasan adalah pikiran negatif berupa belief yang dimiliki individu. Dari pembahasan tersebut, ditemukan bahwa kedua partisipan sudah memiliki pemahaman yang baik mengenai konsep ABC. Akan tetapi, partisipan A terlihat masih ragu saat mengidentifikasi pikiran negatif yang dimilikinya. Peneliti juga menemukan distorsi kognitif yang dialami oleh kedua partisipan.

\section{Sesi 5 : Counter Pikiran Negatif Otomatis (NATs)}

Pada sesi ini, peneliti menjelaskan bahwa terdapat teknik counter yang bisa digunakan untuk mematahkan pikiran negatif tersebut. Peneliti kemudian meminta kedua partisipan untuk menuliskan contoh-contoh counter yang dapat dilakukan oleh terhadap pikiran masing-masing partisipan. Salah satu partisipan, yaitu $\mathrm{R}$, mengatakan bahwa perasaannya menjadi lebih ringan setelah mencoba melakukan counter. Peneliti juga memberikan tugas rumah untuk mengaplikasikan counter tersebut dimaksudkan agar kedua partisipan dapat mengenali perbedaan antara dampak dari pikiran negatif sebelum dan sesudah diberikan counter.

\section{Sesi 6 : Sharing Aplikasi Counter dan Relapse Management}

Sesi ini berfokus pada pengalaman partisipan dalam melakukan counter pikiran negatif. Dengan bimbingan dari peneliti, kedua partisipan menyimpulkan bahwa pikiran yang berbeda akan menghasilkan perasaan yang berbeda pula. Peneliti juga melakukan review dari sesi-sesi yang telah dijalani, dan menyimpulkan bahwa kedua partisipan memiliki motivasi yang tinggi sehingga dapat mengurangi risiko relapse.

\section{Sesi 7 : Terminasi}

Pada sesi terakhir ini, peneliti memberikan kuesioner PAID untuk diisi oleh kedua partisipan agar peneliti dapat melihat hasil post-test. Peneliti kemudian melakukan perbandingan antara skor pre- test dan post-test untuk melihat perbedaan skor sebelum dan sesudah intervensi. Peneliti kemudian menyampaikan review singkat atas sesi- sesi yang sudah dijalankan dengan tujuan melakukan penyegaran informasi bagi partisipan. Terakhir, peneliti memberikan apresiasi kepada kedua partisipan atas kesediaannya mengikuti serangkaian penelitian ini.

\section{Evaluasi Intervensi}

Setelah seluruh sesi selesai dilakukan, peneliti kemudian merangkum hasil evaluasi intervensi. Berikut adalah tabel perbandingan skor PAID serta review pemahaman sebelum dan sesudah kedua partisipan mengikuti intervensi pada Tabel 1. Hasil penelitian menunjukkan bahwa intervensi berbasis pendekatan CBT berhasil untuk menurunkan tingkat diabetes-related distress pada partisipan lansia dalam penelitian ini. 

DENGAN PENYAKIT DIABETES MELLITUS TIPE 1 DAN TIPE 2

Tabel 1. Perbandingan Pra dan Pasca Intervensi Kedua Partisipan

\begin{tabular}{|c|c|c|c|}
\hline $\begin{array}{c}\text { Partis } \\
\text { ipan }\end{array}$ & Aspek & $\begin{array}{c}\text { Pra } \\
\text { Intervensi }\end{array}$ & $\begin{array}{c}\text { Pasca } \\
\text { Intervensi }\end{array}$ \\
\hline \multirow[b]{4}{*}{$\begin{array}{c}\text { Klien } \\
\text { A }\end{array}$} & Skor PAID & 51.25 & 32.50 \\
\hline & $\begin{array}{l}\text { Target } \\
\text { Intervensi }\end{array}$ & \multicolumn{2}{|c|}{$\begin{array}{l}\text { Pikiran negatif } \text { berupa } \\
\text { 'Kenaikan gula darah bukan } \\
\text { merupakan suatu masalah } \\
\text { bagi saya' }\end{array}$} \\
\hline & Kognitif & $\begin{array}{l}\text { Tidak } \\
\text { mengetahui } \\
\text { bahwa } \\
\text { pikiran } \\
\text { dapat } \\
\text { memengaru } \\
\text { hi emosi } \\
\text { dan } \\
\text { perilaku } \\
\end{array}$ & $\begin{array}{l}\text { Memahami } \\
\text { bahwa } \\
\text { pikiran dapat } \\
\text { memengaruhi } \\
\text { emosi dan } \\
\text { perilaku }\end{array}$ \\
\hline & Perilaku & $\begin{array}{l}\text { Tidak } \\
\text { segan } \\
\text { untuk } \\
\text { makan di } \\
\text { luar pola } \\
\text { makan } \\
\text { yang telah } \\
\text { ditetapkan } \\
\text { dokter } \\
\text { meskipun } \\
\text { hal tersebut } \\
\text { membuat } \\
\text { gula } \\
\text { darahnya } \\
\text { naik }\end{array}$ & $\begin{array}{l}\text { Dapat } \\
\text { mempraktikk } \\
\text { an counter } \\
\text { untuk pikiran } \\
\text { negatifnya } \\
\text { tersebut } \\
\text { sehingga A } \\
\text { dapat } \\
\text { menghindari } \\
\text { perilaku yang } \\
\text { mendukung } \\
\text { pikiran } \\
\text { negatifnya } \\
\text { tersebut }\end{array}$ \\
\hline \multirow[b]{4}{*}{$\begin{array}{c}\text { Klien } \\
\mathrm{R}\end{array}$} & Skor PAID & 57.50 & 37.50 \\
\hline & $\begin{array}{l}\text { Target } \\
\text { Intervensi }\end{array}$ & \multicolumn{2}{|c|}{$\begin{array}{l}\text { Pikiran negatif berupa 'Saya } \\
\text { adalah beban bagi orang } \\
\text { lain' }\end{array}$} \\
\hline & Kognitif & $\begin{array}{l}\text { Tidak } \\
\text { mengetahui } \\
\text { bahwa } \\
\text { pikiran } \\
\text { dapat } \\
\text { memengaru } \\
\text { hi emosi } \\
\text { dan } \\
\text { perilaku }\end{array}$ & $\begin{array}{l}\text { Memahami } \\
\text { bahwa } \\
\text { pikiran dapat } \\
\text { memengaruhi } \\
\text { emosi dan } \\
\text { perilaku }\end{array}$ \\
\hline & Perilaku & $\begin{array}{l}\text { Menolak } \\
\text { untuk } \\
\text { berinteraksi } \\
\text { dengan } \\
\text { orang lain }\end{array}$ & $\begin{array}{l}\text { Dapat } \\
\text { mempraktikk } \\
\text { an counter } \\
\text { untuk pikiran } \\
\text { negatifnya } \\
\text { tersebut } \\
\text { sehingga R } \\
\text { dapat } \\
\text { menghindari } \\
\text { perilaku yang } \\
\text { mendukung } \\
\text { pikiran } \\
\text { negatifnya } \\
\text { tersebut }\end{array}$ \\
\hline
\end{tabular}

Tolok ukur efektivitas utama adalah skor PAID. Hal itu ditunjukkan dari adanya penurunan pada skor PAID yang diisi partisipan sebelum dan setelah intervensi. Pada item PAID yang terkait dengan area distres partisipan yang menjadi target intervensi, terjadi penurunan skor yang menunjukkan bahwa partisipan mengalami penurunan tingkat distres.

Sementara itu, penurunan skor pada item-item PAID yang tidak terkait dengan area distres partisipan yang menjadi target intervensi menunjukkan bahwa secara umum intervensi ini berhasil untuk menurunkan diabetes- related distress.

Tolok ukur keberhasilan intervensi yang lainnya adalah tugas-tugas yang berhasil dikerjakan oleh partisipan. Dari tugas-tugas tersebut terlihat bahwa terdapat perubahan pikiran negatif menjadi pikiran yang lebih positif pada partisipan. Berdasarkan hasil yang ditunjukkan oleh kedua tolok ukur tersebut, maka dapat dikatakan bahwa intervensi berbasis pendekatan CBT dapat digunakan untuk menurunkan tingkat diabetes-related distress pada penderita DM tipe 1 dan tipe 2.

Partisipan A mengalami diabetesrelated distress sebagai akibat dari rasa bosan dan tertekan yang dialaminya dalam menaati regimen DM selama bertahun-tahun lamanya. Hal tersebut membuat dirinya kerap melanggar regimen DM yang telah ditetapkan, terutama dalam hal mengatur pola makan. Tingkah laku A tersebut sejalan dengan hasil penelitian yang dilakukan oleh Lloyd, dkk (2013), yang menemukan bahwa diabetes-related distress merupakan salah satu penghalang utama terhadap suksesnya manajemen DM.

Sementara itu, partisipan B yang memiliki DM tipe 2 sejak 40 tahun lalu mengalami diabetes-related distress yang diakibatkan oleh salah satu komplikasi dari DM, yaitu glaukoma. Keterbatasan 
dalam hal penglihatan membuatnya merasa rendah diri sehingga ia enggan beraktivitas di luar rumahnya. Hal tersebut sesuai dengan yang dikemukakan oleh Faber-Wildeboer, dkk (2012), bahwa distres emosional terkait DM yang kerap dialami oleh penderita DM di antaranya adalah rasa bersalah, frustrasi, marah, kecewa, ataupun takut.

Reddy, dkk (2013) mengemukakan bahwa diabetes-related distress dapat dilatarbelakangi oleh minimnya pengetahuan terkait penyakit serta dampaknya pada penderita DM. Dengan demikian, adanya psikoedukasi sebagai bagian dari rangkaian intervensi pada penelitian ini merupakan salah satu faktor yang melatarbelakangi turunnya tingkat diabetes-related distress partisipan.

Salah satu dampak yang dari adanya diabetes-related distress adalah hubungan interpersonal (Tol, 2012). Hal tersebut terbukti pada kedua partisipan. A yang merasa bahwa istrinya terlalu sering mengingatkannya untuk menjaga pola makan kerap merasa kesal. Sementara itu, B yang menderita glaukoma sebagai salah satu gangguan yang berasal dari DM tipe 1 yang dideritanya menjadi enggan bergaul dengan orang lain karena keterbatasannya tersebut.

Sorocco dan Lauderdale (2011) mengemukakan bahwa klien berusia lanjut seringkali mengikuti terapi psikologis berupa CBT berdasarkan alasan-alasan eksternal, seperti persuasi yang dilakukan oleh anak, pasangan, ataupun dokternya. Pada kasus A dan B, terlihat bahwa keduanya mendapatkan persuasi untuk mengikuti intervensi dengan baik dari lingkungan terdekatnya. A mendapatkan persuasi dari istrinya yang mendorongnya untuk menjalankan teknik-teknik intervensi yang diajarkan oleh peneliti. Sementara itu, B mendapatkan dukungan dari anakanaknya, yang ditunjukkan oleh anaknya yang selalu memantau perkembangannya serta memotivasinya untuk mengikuti intervensi yang diberikan sebaik-baiknya.

Kehadiran peneliti sebagai terapis yang mendatangi kedua partisipan ke rumahnya masing-masing juga membawa efek terapeutik tersendiri bagi keduanya, terutama bagi B. Efek terapeutik ini dapat muncul karena kedatangan peneliti dapat menghadirkan dukungan sosial bagi mereka, khususnya saat mereka bercerita dan kemudian peneliti mendengarkan dan memperhatikannya. Hal tersebut sesuai dengan karakteristik dari lansia yang juga merupakan pertimbangan saat menentukan treatment untuk penderita DM berusia lanjut, yaitu dukungan sosial yang minim (Araki \& Ito, 2009).

Hasil dari penelitian ini
menunjukkan bahwa intervensi menggunakan pendekatan CBT dengan fokus pada modifikasi pikiran negatif otomatis (NATs) menjadi positif yang berlangsung sebanyak 7 sesi. Dengan demikian, intervensi yang tergolong singkat dapat membantu untuk mengurangi diabetes-related distress pada lansia dengan DM tipe 1 dan 2. Hasil penelitian ini penting sebagai usaha untuk memberikan pelayanan psikologis yang aplikatif, cepat, dan ekonomis.

Manfaat lain dari penelitian ini adalah penelitian ini secara tidak langsung menjadi sosialisasi mengenai urgensi untuk mengenali masalah psikologis yang dimiliki individu. Partisipan penelitian mengaku tidak mengetahui bahwa variabel psikologis berupa diabetesrelated distress dapat memberikan dampak negatif terhadap penyakit yang dimilikinya, yaitu DM. Ketidaktahuan ini tidak hanya dialami oleh partisipan penelitian, melainkan juga pada masyarakat umum. Dengan demikian, melalui pemberian intervensi ini, partisipan dapat merasakan manfaat dari terapi non-farmakologis berupa CBT. 

DENGAN PENYAKIT DIABETES MELLITUS TIPE 1 DAN TIPE 2

Salah satu keterbatasan pada penelitian ini terletak pada terbatasnya jumlah sampel penelitian, sehingga tidak dapat mencapai signifikansi statistik. Keterbatasan berikutnya adalah adanya partisipan yang memiliki keterbatasan fisik, yaitu partisipan R. Hal itu membuat peneliti memodifikasi cara penyampaian materi, pemberian tugas rumah, dan lain sebagainya. Kenyataan tersebut sejalan dengan penggunaan intervensi berbasis CBT yang telah banyak diadaptasi untuk klien dengan berbagai latar, seperti yang dikemukakan oleh Beck (2011). Keterbatasan selanjutnya adalah intervensi berbasis CBT dalam penelitian ini yang tidak mengungkap dan mengubah core belief partisipan, melainkan hanya berfokus pada pikiran negatif partisipan. Akan tetapi, keadaan partisipan yang berusia lanjut tidak memungkinkan intervensi ini untuk melangsungkan penggalian serta modifikasi core belief yang dimiliki, ditinjau dari segi waktu dan juga kemampuan partisipan. Keterbatasan terakhir adalah waktu penelitian yang cenderung terbatas. Keterbatasan waktu tersebut membuat peneliti tidak dapat melakukan follow-up dengan jarak waktu setidaknya satu hingga tiga bulan setelah asesmen pascaintervensi, sedangkan follow-up tersebut penting untuk dilakukan terkait dengan relapse prevention. Terkait dengan relapse prevention tersebut, apabila partisipan benar-benar berusaha dalam menjalankan teknik-teknik yang telah diberikan selama intervensi, maka kemungkinan relapse terjadi akan dapat diminimalisasi.

\section{DAFTAR PUSTAKA}

Araki, A. \& Ito, H. (2009). Diabetes mellitus and geriatric syndromes. Geriatrics International, 9, 105 - 114 .
Beck, J. S. (2010). Cognitive behavior therapy: basics and beyond $2^{\text {nd }}$ ed. New York: The Guilford Press.

Davazdahemamy, M. H., Mehrabi, A., Attari, A. \& Roshan, R. The effectiveness of cognitivebehavioral stress management training on glycemic control, psychological distress and quality of life in people with type2 diabetes. Iranian Journal of Clinical Psychology, 1 (1), 57 64.

Faber-Wildeboer, A. T., Os-Medendorp. H., Kooy, A. \& Sol, B. G. (2012). Prevalence and risk factors of depression and diabetes-related emotional distress in patients with type 2 diabetes: A cross-sectional study. Journal of Nursing Education and Practice, 3 (6), 61 -69 .

Franks, M. M., Lucas, T., Stephens, M. A., Rook, K. S., \& Gonzalez, R. (2010). Diabetes distress and depressive symptoms: a dyadic investigation of older patients and their spouses. Family Relations, 59, $599-610$.

Lloyd, C. E., Pouwer, F., \& Hermanns, N. (2013). Screening for Depression and Other Psychological Problems in Diabetes. London: Springer.

Lustman, P. J., Griffith, L. S., Freedland, K. E., Kissel, S. S. \& Clouse, R. E. (1998). Cognitive behavior therapy for depression in type 2 diabetes mellitus: a randomized, controlled trial. Ann Intern Med, (129), $613-621$.

Munshi, M. N. \& Lipsitz, L. A. (2007). Geriatric diabetes. New York: Informa Healthcare, Inc.

Pouwer, F. (2009). Should We Screen for Emotional Distress in Type 2 Diabetes Mellitus? 
www.medscape.org (diunduh pada 28 Maret 2013).

Reddy, J., Wilhelm, K. \& Campbell, L. (2013). Putting PAID to diabetesrelated distress: the potential utility of the problem areas in diabetes (PAID) scale in patients with diabetes. Psychosomatics, 54, $44-51$.

Sarafino, E. P. \& Smith, T. W. (2011). Health psychology $7^{\text {th }}$ ed. New Jersey: John Wiley \& Sons.

Snoek, F. J. \& Skinner, T. C. (2005). Psychology in diabetes care $2^{\text {nd }}$ ed. New Jersey: John Wiley \& Sons.

Sorocco, K. H. \& Lauderdale, S. (2011). Cognitive behavior therapy with older adults: Innovations across care settings. New York: Springer. Tol, A., Baghbanian, A., Sharifirad, G., Shojaezaideh, D., Eslami, A., Alhani, F., \& Mohamadreza, M. T. (2012). Predictors of selfmanagement behaviors among type 2 diabetes patients. J. Basic. Appl. Sci. Res., 2 (3), $2270-$ 2274.

Wetherell, J. L., Sorrell, J. T., Thorp, S. R., \& Patterson, T. L. (2005). Psychological interventions for late-life anxiety: a review and early lessons from the CALM study. $J$ Geriatr Psychiatry Neurol, $\quad 18, \quad 72-82$. 
